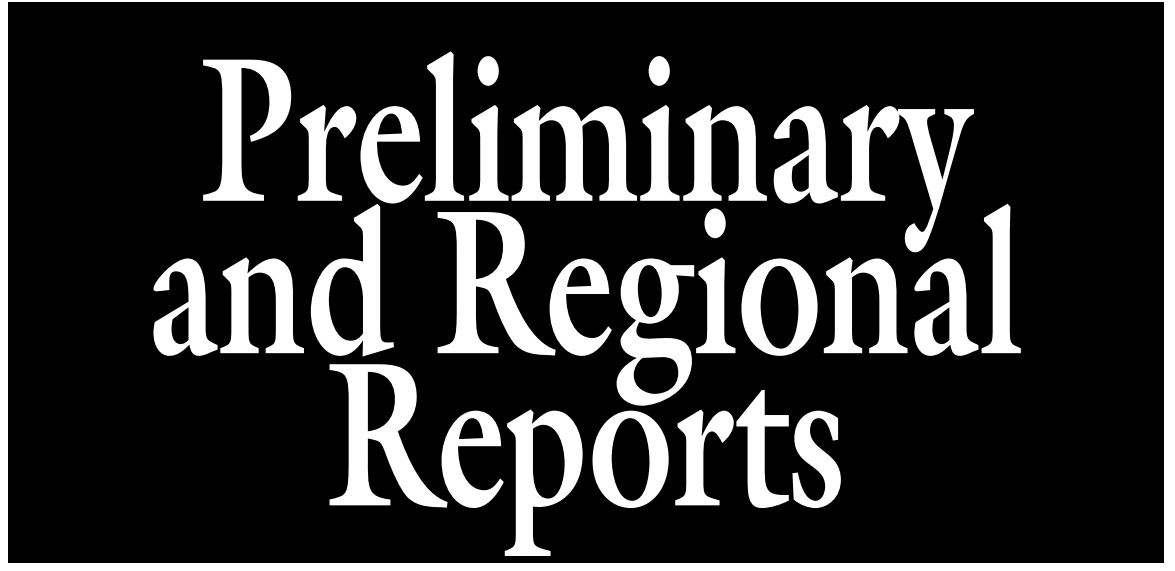

\section{Assessment of Subirrigation Performance in Eucalyptus Seedling Production}

\author{
Maycon Diego Ribeiro ${ }^{1,4,5}$, Rhuanito Soranz Ferrarezi ${ }^{2,4}$, \\ and Roberto Testezlaf ${ }^{3}$
}

ADDITIONAL INDEX WORDs. capillary irrigation, greenhouse, nutrient solution, recycle, water reuse

SumMARY. We evaluated the performance and determined the efficiency parameters of an automated subirrigation system in a commercial greenhouse facility for clonal eucalyptus (Eucalyptus sp.) seedling production to improve subirrigation management practices. A methodology based on the mass balance of the irrigation system was established to determine the volumes of nutrient solution (NS) applied, drained, stored, evapotranspirated, and leaked in each subirrigation bench. The application, drainage, and NS dwell time in the $55-\mathrm{cm}^{3}$ conic containers $(0.125 \mathrm{~m}$ height $\times 0.03 \mathrm{~m}$ diameter) and the depth of NS reached inside the bench were also assessed. The values of application efficiency, irrigation efficiency and system transport (supply and drainage), and disposal losses of NS were estimated for each bench and inferred for the entire subirrigation system. The benches had average application and irrigation efficiency values of $0.84 \%$ and $98.38 \%$, respectively. The system showed irrigation efficiency values of $27.59 \%$ and the sum lost by transport, leakings, and disposal in the water treatment plant of $72.41 \%$. The continuous return of NS because of the high irrigation frequency contributed to this loss, resulting in 10,070 L of NS consumed by the plants and 26,430 L lost after 15 days of cultivation. Our results demonstrated that the system presented an adequate irrigation efficiency, but a low application efficiency caused by the constant return of NS because of the high irrigation frequency and the excess of losses from leaking and disposal of NS after 15 days of cultivation. Nevertheless, the system operated like a hydroponic system, which kept the containers partially immersed in the NS and did not use the full substrate container capacity to provide adequate moisture. This reduced the overall system irrigation and the substrate storage efficiencies, which needs to be improved by proper equipment design, operation, water and nutrients use efficiency, and management to achieve all the benefits that subirrigation possess.

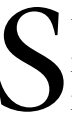
ubirrigation has the potential to increase the irrigation efficiency in greenhouse potted production, due to the recirculation of NS, reduction in water loss and chemical leaching, and less environmental contamination caused by the improper disposal of nutrients and pesticides (Montesano et al., 2010). This system can increase crop production through moisture and control irrigation based on plant water use (Ferrarezi and van Iersel, 2011), providing adequate water and nutrient supply without affecting fertilizer availability (Andriolo et al., 2001). Furthermore, subirrigation presents lower risk of pathogens spread and higher effectiveness of pesticides application when compared with other open-cycle systems (van Iersel et al., 2001).

However, subirrigation may present drawbacks for growers, such as high initial investment cost and a lack of established crop management guidelines. To reduce the cost and increase the availability of appropriate information concerning subirrigation, it is necessary to expand the demand for this type of system with the construction and dissemination of new equipment.

The use of subirrigation in greenhouse production is nearly nonexistent in Brazil because of the unavailability of equipment and technical information needed to guide the growers regarding commercial applications. Thus, handcrafted systems have been manufactured without precise design criteria and applied empirically. Therefore, the characterization of these systems operating in commercial production would increase the information about the quality and efficiency of handcrafted systems, stimulate system employment, guide new equipment designs, and thus allow equipment manufacturers and producers of seedlings and plants in conic containers to benefit from subirrigation. The knowledge will help to develop specific engineering design criteria to ensure adequate efficiency and address the needs for containerized production.

Our objectives were to evaluate the performance and to determine the efficiency parameters of an automated subirrigation system in a commercial greenhouse facility for clonal eucalyptus seedling production to improve subirrigation management practices.

\section{Materials and methods}

System DesCription. This study was conducted in Dec. 2011. The handcrafted subirrigation system evaluated was installed in a commercial greenhouse facility for clonal eucalyptus seedling production in Mogi Guaçu, Brazil. The climate of the region was classified as Cwa according to the Köppen system (Peel et al., 2007). 
During the experimental period, the average daily temperature and relative humidity from outdoor were (mean \pm SD) $23.6 \pm 0.9^{\circ} \mathrm{C}$ and $88.3 \% \pm 3.1 \%$, respectively, and the daily light integral averaged $50.2 \pm 5.1 \mathrm{~mol} \cdot \mathrm{m}^{-2} \cdot \mathrm{d}^{-1}$.

The system had been in operation for $\approx 10$ years and had been designed and manufactured by the grower in aluminum (Fig. 1). The entire system was composed of six irrigation units distributed in nine polyethylene venlo greenhouses (Van der Hoeven, Artur Nogueira, Brazil), with a total production area of $1710 \mathrm{~m}^{2}$ (Fig. 2A). Each unit had three blocks of 21 subirrigation benches (dimension of $2.85 \mathrm{~m}$ length $\times 1.19 \mathrm{~m}$ width $\times 0.09 \mathrm{~m}$ height) fitted over rolling rails at a height of $0.60 \mathrm{~m}$ from the ground (Fig. 2B). Each bench was filled with 600 conic containers of $55-\mathrm{cm}^{3}$ (dimension of $0.125 \mathrm{~m}$ height $\times 0.03 \mathrm{~m}$ diameter) (Aluminox, Jundiaí, Brazil), open at the bottom to allow drainage, inserted in a $5-\mathrm{cm}$ polystyrene foam plate, where eucalyptus stock plants were grown in a coconut coir substrate produced by the company. Each irrigation unit was individually supplied with NS by pumping from three reservoirs, two with a volume of $7000 \mathrm{~L}$ and one of $5000 \mathrm{~L}$, totaling $19,000 \mathrm{~L}$ (Fig. 2B). These reservoirs were refilled with an average volume of $2500 \mathrm{~L}$ of NS every $2 \mathrm{~d}$ to replace the volume consumed by the plants and lost by bench leaks and transport $(2500 \mathrm{~L}$ every $2 \mathrm{~d} \times 7 \mathrm{~d}=17,500 \mathrm{~L}$ ). Because of changes in its chemical properties, all the NS was changed every $15 \mathrm{~d}$ and discarded in the company water treatment plant. Thus, each irrigation unit

\footnotetext{
This research was supported by the School of Agricultural Engineering (FEAGRI), by the Brazilian National Council of Technological and Scientific Development $(\mathrm{CNPq}$, scholarship to the first author and grant no. 479.665/2009-5), and by São Paulo Research Foundation (FAPESP, no. 2012/01734-5).

Acknowledgments are made to the company that authorized the performance assessment and to the anonymous reviewers for their suggestions.

${ }^{1}$ Center for Technology and Natural Resources, Federal University of Campina Grande, 882 Aprígio Veloso Street, Campina Grande, PB 58109-900, Brazil

${ }^{2}$ Department of Horticulture, University of Georgia, 1111 Miller Plant Science Building, Athens, GA 30605

${ }^{3}$ School of Agricultural Engineering, University of Campinas, 501 Cândido Rondon Avenue, Campinas, SP 13083-875, Brazil

${ }^{4}$ These authors contributed equally to this work as the joint first authors.

${ }^{5}$ Corresponding author. E-mail: ribeiro.md@gmail.

com.
}

used a total of 36,500 L of NS every $15 \mathrm{~d}$.

Daily fertigations were performed every $2 \mathrm{~h}$ between 0700 and $1700 \mathrm{HR}$, with a total of six applications per bench per day. The NS used had a $\mathrm{pH}$ of 5.02 , electrical conductivity of $2.1 \mathrm{dS} \cdot \mathrm{m}^{-1}$, and the nutrient concentrations were $178 \mathrm{mg} \cdot \mathrm{L}^{-1}$ nitrogen (N) [1:1 nitrate $\left(\mathrm{NO}_{3}\right)$-N:ammonium $\left.\left(\mathrm{NH}_{4}\right)-\mathrm{N}\right], 71 \mathrm{mg} \cdot \mathrm{L}^{-1}$ phosphorus, $197 \mathrm{mg} \cdot \mathrm{L}^{-1}$ potassium, $95 \mathrm{mg} \cdot \mathrm{L}^{-1}$ calcium, $50 \mathrm{mg} \cdot \mathrm{L}^{-1}$ magnesium, 70 $\mathrm{mg} \cdot \mathrm{L}^{-1}$ sulfur, $0.5 \mathrm{mg} \cdot \mathrm{L}^{-1}$ boron, 0.1 $\mathrm{mg} \cdot \mathrm{L}^{-1}$ copper, $7.67 \mathrm{mg} \cdot \mathrm{L}^{-1}$ iron $[$ ferrous sulfate $\left.\left(\mathrm{FeSO}_{4}\right)\right], 1.65 \mathrm{mg} \cdot \mathrm{L}^{-1}$ manganese, 0.2 molybdenum, and 0.57 zinc. All trace elements were chelated using ethylenediaminetetraacetic acid.

The NS was pumped into the benches with a 5 -horsepower pump (WEG, Jaraguá do Sul, Brazil) connected with a $50-\mathrm{mm}$ PVC pipe (Amanco, Sumaré, Brazil). Along this manifold pipe, 21 inlet tubes discharged the NS to the benches by the opening and closing of three solenoid valves (Amanco). Consequently, when one valve was opened the other two remained closed, thereby irrigating one block at a time inside the unit (Fig. 2A).

The NS applied to the benches was drained through 104 outlet holes with a diameter of $0.4 \mathrm{~cm}$ to avoid debris obstruction, totaling an area of $13.07 \mathrm{~cm}^{2}$ (Fig. lb), and drilled on the same side of the inlets. Underneath the drainage holes, a small sink was built to collect the NS and limit the drainage flow having an opening with a diameter of $1.27 \mathrm{~cm}$ and an area of $4.91 \mathrm{~cm}^{2}$ (Fig. ld). The collected NS was then conveyed to a drain trough and followed drainage pipes to the reservoirs for reuse (Fig. ld).
EVALUATION METHODOLOGY. We modified the drip evaluation methodology proposed by Keller and Karmeli (1975) to select the sampling points in the benches. Four of the six units were chosen with one block of benches per unit and four benches per block as replications, totaling 16 benches or assessment points to represent the full subirrigation system (marked in red Fig. 2A).

We established a practical approach to assess the performance of this handcrafted subirrigation system. The estimation of efficiency parameters was established based on the variables that define the water mass balance of each bench and the subirrigation system (i.e., on the NS input and output). We measured the volume and frequency of NS application and drainage, the volume of NS stored in the substrate, and estimated the daily evapotranspiration of the eucalyptus seedlings during the evaluation procedure.

The volume of NS applied to each bench was measured using water flow meters (Unimag-TM II; Tecnobrás/ Itrón, Americana, Brazil) installed in the inlet tubes. The NS application time for an irrigation event was determined using a stopwatch, and the input flow rate was calculated from the two measured variables.

The volume and time of drainage were determined in each bench to obtain the drainage output flow rate. The drained volume was collected simultaneously from the four selected benches of each unit every $2 \mathrm{~min}$, allowing the determination of the variation of the mean drainage flow rate in this time period and the total drained NS volume. This sample interval was defined by the hydraulic head variation within the bench, which

\begin{tabular}{llll}
\hline $\begin{array}{l}\text { Units } \\
\text { To convert U.S. to SI, } \\
\text { multiply by }\end{array}$ & U.S. unit & SI unit & $\begin{array}{l}\text { To convert SI to U.S., } \\
\text { multiply by }\end{array}$ \\
\hline 0.3048 & $\mathrm{ft}$ & $\mathrm{m}$ & 3.2808 \\
0.0929 & $\mathrm{ft}^{2}$ & $\mathrm{~m}^{2}$ & 10.7639 \\
3.7854 & gal & $\mathrm{L}$ & 0.2642 \\
0.7457 & horsepower & $\mathrm{kW}$ & 1.3410 \\
2.54 & inch(es) & $\mathrm{cm}$ & 0.3937 \\
25.4 & inch(es) & $\mathrm{mm}$ & 0.0394 \\
6.4516 & inch & $\mathrm{cm}^{2}$ & 0.1550 \\
16.3871 & inch & $\mathrm{cm}^{3}$ & 0.0610 \\
1.6093 & mile $(\mathrm{s})$ & $\mathrm{km}$ & 0.6214 \\
1 & mmho/cm & $\mathrm{dS} \cdot \mathrm{m}^{-1}$ & 1 \\
1 & $\mathrm{ppm}$ & $\mathrm{mg} \cdot \mathrm{L}^{-1}$ & 1 \\
$\left({ }^{\circ} \mathrm{F}-32\right) \div 1.8$ & ${ }^{\circ} \mathrm{F}$ & ${ }^{\circ} \mathrm{C}$ & $\left({ }^{\circ} \mathrm{C} \times 1.8\right)+32$
\end{tabular}


altered the drainage output as a function of time.

The weight of 15 containers with plants was determined before and after an irrigation event using a scale (EMB 600-2; Kern, Balingen, Germany). The difference between both measurements determined the amount of NS retained in a container. This value was multiplied by the number of plants per bench (600), resulting in the volume of NS stored per bench. The amount of water applied per plant can be estimated by dividing the applied water minus the return by the number of plants.

The evapotranspiration volume was obtained by Eq. [1], adopting a crop coefficient value for eucalyptus seedlings production based on Allen et al. (1998). We calculated the reference evapotranspiration $\left(\mathrm{ET}_{\mathrm{o}}\right)$ value using meteorological data from a
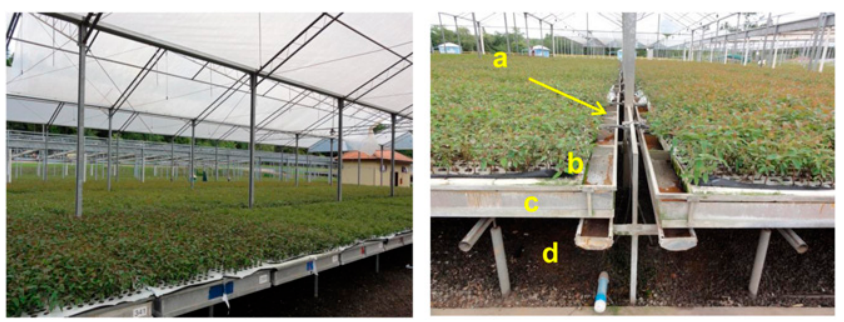

Fig. 1. Overview of the handcrafted subirrigation system evaluated in a commercial greenhouse facility for clonal eucalyptus seedling production: (a) water supply, (b) outlet holes to avoid debris obstruction, (c) ebb-and-flow benches, and (d) drain trough.

(A)

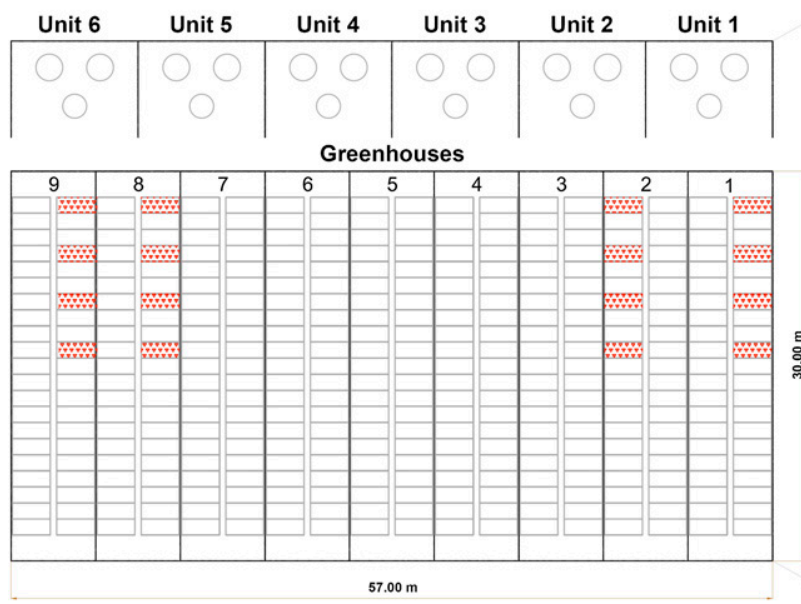

weather station located 3 miles away from the experimental site. The $\mathrm{ET}_{\mathrm{o}}$ value was estimated using the FAO Penman-Monteith equation from Allen et al. (1998) (equal to $4.5 \mathrm{~mm} \cdot \mathrm{d}^{-1}$ ). We used this procedure because few growers monitor environmental conditions inside the greenhouse due to the highly variable air movement and the lack of the required fetch in enclosed growing environments. As van Der Post et al. (1974), Montero et al. (1985), Rosenberg et al. (1989), and Fernández et al. (2010) indicated that the evapotranspiration inside the greenhouse is around $60 \%$ to $80 \%$ of the exterior, we used the value of $70 \%$ to calculate the $\mathrm{ET}_{\mathrm{o}}$ inside the greenhouse $\left(3.15 \mathrm{~mm} \cdot \mathrm{d}^{-1}\right)$.

$$
\mathrm{V}_{\mathrm{ET}}=\frac{\mathrm{K}_{\mathrm{c}} \times \mathrm{ET}_{\mathrm{o}} \times \mathrm{A}}{\mathrm{NHSD}}
$$

where $V_{\mathrm{ET}}$ is the evapotranspiration volume per bench (liters), $\mathrm{K}_{\mathrm{c}}$ is the crop coefficient (equal to 1 ), $\mathrm{ET}_{\mathrm{o}}$ is the reference evapotranspiration in the greenhouse (equal to $3.15 \mathrm{~mm} \cdot \mathrm{d}^{-1}$ ), $A$ is the subirrigation bench area (equal to $3.4 \mathrm{~m}^{2}$ ), and NHSD is the number of hours of sunshine per day (equal to $10 \mathrm{~h} \cdot \mathrm{d}^{-1}$ ).

The volume of NS leaked per bench in an irrigation event was estimated from the difference between the total volume of NS applied to each bench and the sum of drained, stored, and evapotranspirated volumes (Eq. [2]). We determined the total of NS leaked in the benches and in the system by the differences between the volume applied and lost. This approach was used because the leaking was variable over the benches, not allowing proper comparison among the units (data not shown).

$$
\mathrm{V}_{\mathrm{lb}}=\mathrm{V}_{\mathrm{ab}}-\left(\mathrm{V}_{\mathrm{db}}+\mathrm{V}_{\mathrm{sb}}+\mathrm{V}_{\mathrm{ET}}\right)
$$

where $V_{l b}$ is the leaked volume of NS per bench in an irrigation event (liters), $\mathrm{V}_{\mathrm{ab}}$ is the applied volume of NS per bench in an irrigation event (liters), $\mathrm{V}_{\mathrm{db}}$ is the drained volume of NS per bench in an irrigation event (liters), and $\mathrm{V}_{\mathrm{sb}}$ is the stored volume of NS per bench in an irrigation event (liters).

The height of NS applied to the container was measured from the bottom with a ruler. The dwell time of NS in the containers was also determined. This period started at the time that the NS touched the container and ended when there was no longer contact between both at the end of drainage.

The determination of these variables permitted the calculation of the following efficiency parameters: the bench substrate storage efficiency $\left[\mathrm{SE}_{\mathrm{b}}(\mathrm{Eq}\right.$. [3])], bench application efficiency $\left[\mathrm{AE}_{\mathrm{b}}(\mathrm{Eq}\right.$. [4])], bench irrigation efficiency $\left[\mathrm{IE}_{\mathrm{b}}(\mathrm{Eq} .[5])\right]$, and the bench leaking $\left[\mathrm{L}_{\mathrm{b}}\right.$ (Eq. [6])] (adapted from Heermann and Solomon, 2007). The application efficiency represents the volume of water consumed by the plants from the water available in the substrate (sum of the evapotranspired and stored volumes). The irrigation efficiency denotes the total volume of water available to the plant (Heermann and Solomon, 2007).

Fig. 2. Layout of the subirrigation system for clonal eucalyptus seedling production with the sampling points in red (A) and details of nutrient solution application and drainage systems in a subirrigation unit (B). Every irrigation line in the greenhouses had $15 \mathrm{~m}$ each; $1 \mathrm{~m}=3.2808 \mathrm{ft}$. 


$$
\begin{aligned}
\mathrm{SE}_{\mathrm{b}} & =\frac{\mathrm{V}_{\mathrm{sb}}}{\mathrm{V}_{\mathrm{ab}}} \\
\mathrm{AE}_{\mathrm{b}} & =\frac{\mathrm{V}_{\mathrm{sb}}+\mathrm{V}_{\mathrm{ET}}}{\mathrm{V}_{\mathrm{ab}}} \\
\mathrm{IE}_{\mathrm{b}} & =\frac{\mathrm{V}_{\mathrm{sb}}+\mathrm{V}_{\mathrm{ET}}+\mathrm{V}_{\mathrm{db}}}{\mathrm{V}_{\mathrm{ab}}} \\
\mathrm{L}_{\mathrm{b}} & =\frac{\mathrm{V}_{\mathrm{lb}}}{\mathrm{V}_{\mathrm{ab}}} \times 100
\end{aligned}
$$

The performance of each irrigation unit was evaluated using the efficiency parameters derived from the three blocks of benches for an irrigation cycle of $15 \mathrm{~d}$, after which the NS was discarded. The total volume of NS applied to each irrigation unit was estimated for this period. The obtained value was separated into the consumed volume (volume stored in the substrate, evapotranspirated by plants, or leaked in the benches) and loss volume (volumes of NS lost in transport and discarded after the irrigation cycle). Consequently, we determined the unit storage efficiency $\left[\mathrm{SE}_{\mathrm{u}}(\right.$ Eq. [7])], unit irrigation efficiency [ $\mathrm{IE}_{\mathrm{u}}$ (Eq. [8])], and the sum lost in the unit by the water supply, drainage, leakings, and disposal in the water treatment plant after $15 \mathrm{~d}$ [ $\mathrm{L}_{\mathrm{u}}$ (Eq. [9])].

$\mathrm{SE}_{\mathrm{u}}=\frac{\mathrm{IC} \times \mathrm{N}_{\mathrm{b}} \times \mathrm{NI}_{\mathrm{d}} \times \mathrm{V}_{\mathrm{sb}}}{\mathrm{V}_{\mathrm{i}}+\left[\mathrm{V}_{\mathrm{r}} \times\left(\mathrm{IC} / \mathrm{F}_{\mathrm{r}}\right)\right]}$

where IC is the irrigation cycle (15 d), $\mathrm{N}_{\mathrm{b}}$ is the number of benches per irrigation unit $(63), \mathrm{NI}_{\mathrm{d}}$ is the number of irrigations per day per irrigation unit (6),
$\mathrm{V}_{\mathrm{i}}$ is the initial volume of NS available per irrigation unit $(19,000 \mathrm{~L}), \mathrm{V}_{\mathrm{r}}$ is the replenishment volume of $\mathrm{NS}$ per irrigation unit $(2500 \mathrm{~L})$, and $\mathrm{F}_{\mathrm{r}}$ is the replenishment frequency per irrigation unit (2d).

$$
\begin{aligned}
\mathrm{IE}_{\mathrm{u}}= & \mathrm{IC} \times \mathrm{N}_{\mathrm{b}} \times \mathrm{NI}_{\mathrm{d}} \times \mathrm{V}_{\mathrm{ab}} \\
& \frac{+\left(\mathrm{IC} \times \mathrm{N}_{\mathrm{b}} \times \mathrm{NI}_{\mathrm{d}} \times \mathrm{V}_{\mathrm{sb}}\right)}{\mathrm{V}_{\mathrm{i}}+\left[\mathrm{V}_{\mathrm{r}} \times\left(\mathrm{IC} / \mathrm{F}_{\mathrm{r}}\right)\right]}[8] \\
\mathrm{L}_{\mathrm{u}}= & \frac{\mathrm{IC} \times \mathrm{N}_{\mathrm{b}} \times \mathrm{NI}_{\mathrm{d}} \times \mathrm{V}_{\mathrm{pb}}+\mathrm{V}_{\mathrm{td}}}{\mathrm{V}_{\mathrm{i}}+\left[\mathrm{V}_{\mathrm{r}} \times\left(\mathrm{IC} / \mathrm{F}_{\mathrm{r}}\right)\right]} \\
& \times 100
\end{aligned}
$$

where $\mathrm{V}_{\mathrm{td}}$ is the volume of NS lost by transport (water supply and drainage) and disposal at the end of the irrigation cycle (liters).

STATistics. Four units were chosen as treatments and each sampling in different blocks in four benches was considered a replication in the statistical analyses to allow data comparison among different areas in the greenhouse. All results were submitted to variance analysis and Tukey's honestly significant difference mean separation test using the statistical software SAS (version 9.2; SAS Institute, Cary, NC).

\section{Results and discussion}

SUBIRRIGATION BENCH VARIABLES. The applied flow rates were significantly different among the units $[P=$ 0.001 (Table 1)], and the drainage

\begin{tabular}{|c|c|c|c|c|c|c|c|}
\hline \multirow[b]{2}{*}{ Unit } & \multicolumn{2}{|c|}{ Flow rate $\left(L \cdot \min ^{-1}\right)^{z}$} & \multicolumn{5}{|c|}{ Volume $(\mathrm{L})^{\mathrm{z}}$} \\
\hline & $\mathbf{Q}_{\mathrm{ab}}$ & $\mathbf{Q}_{\mathrm{db}}$ & $\mathrm{V}_{\mathrm{ab}}$ & $\mathrm{V}_{\mathrm{db}}$ & $\mathrm{V}_{\mathrm{sb}}$ & $\mathrm{V}_{\mathrm{ET}}$ & $V_{l b}$ \\
\hline 1 & $21.83 \mathrm{a}^{\mathrm{y}}$ & $4.26 \mathrm{NS}^{\mathrm{y}}$ & $241.2 \mathrm{a}$ & $235.4 \mathrm{a}$ & $0.61 \mathrm{NS}$ & $1.07 \mathrm{NS}$ & $4.11 \mathrm{Ns}$ \\
\hline 2 & $16.24 \mathrm{c}$ & $4.25 \mathrm{NS}$ & $208.4 \mathrm{ab}$ & $203.8 \mathrm{ab}$ & $0.69 \mathrm{NS}$ & $1.07 \mathrm{NS}$ & $2.79 \mathrm{Ns}$ \\
\hline 5 & $20.24 \mathrm{ab}$ & $4.17 \mathrm{NS}$ & $222.7 \mathrm{ab}$ & $216.8 \mathrm{ab}$ & $0.79 \mathrm{NS}$ & $1.07 \mathrm{NS}$ & $3.99 \mathrm{Ns}$ \\
\hline 6 & $17.59 \mathrm{bc}$ & $3.92 \mathrm{NS}$ & $193.5 \mathrm{~b}$ & $188.3 \mathrm{~b}$ & $0.73 \mathrm{NS}$ & $1.07 \mathrm{NS}$ & $3.43 \mathrm{Ns}$ \\
\hline Mean & 18.98 & 4.15 & 216.44 & 211.08 & 0.71 & 1.07 & 3.58 \\
\hline$P$ value & 0.001 & 0.469 & 0.012 & 0.01 & 0.865 & 一 & 0.893 \\
\hline $\mathrm{CV}(\%)^{\mathrm{x}}$ & 7.60 & 7.91 & 7.96 & 7.77 & 43.67 & - & 74.72 \\
\hline
\end{tabular}
flow rate did not show significant differences among the units $[P=$ 0.469 (Table 1)].

Table 1. Nutrient solution (NS) applied $\left(\mathrm{Q}_{\mathrm{ab}}\right)$ and drained $\left(\mathrm{Q}_{\mathrm{db}}\right)$ flow rates, and applied $\left(\mathrm{V}_{\mathrm{ab}}\right)$, drained $\left(\mathrm{V}_{\mathrm{db}}\right)$, stored $\left(\mathrm{V}_{\mathrm{sb}}\right)$, evapotranspirated $\left(\mathrm{V}_{\mathrm{ET}}\right)$, and leaked $\left(\mathrm{V}_{\mathrm{lb}}\right)$ volumes of NS per bench per irrigation event in clonal eucalyptus seedling production. Data are the means of four replications.

${ }^{\mathrm{z}} \mathrm{l} \mathrm{L}=0.2642 \mathrm{gal}$.

${ }^{y}$ Means followed by different letters in the column differ statistically by Tukey's test $(P<0.05)$; Ns $=$ Nonsignificant. ${ }^{x}$ Coefficient of variation.
As a consequence of the variation in the input flow rate, there were also significant differences in the applied volume of NS for the benches within each unit $[P=0.012$ (Table 1$)]$, that ranged up to $25 \%$ (from 193.5 to $241.2 \mathrm{~L}$ ). These differences may have resulted from factors such as variation in the system pressure-which had multiple inlets between the first and last bench - or variations at the pump operation point caused by differences in head loss in the manifold pipe. The occurrence of leakings or obstruction in the inlet pipes that feed the benches could be other possible explanations as well.

The volume of NS drained back to the reservoir was significantly different in the units $[P=0.01$ (Table 1$)]$, and corresponded to $\approx 97 \%$ of the volume applied per bench per irrigation event.

An average volume of $0.71 \mathrm{~L}$ of NS was stored in the substrate per bench, with no significant difference among units $[P=0.865$ (Table 1 ) $]$. A small quantity of substrate was observed within the containers due to intense radial growth, which determined loss of substrate during the system operation and resulted in a low volume of NS stored in the container. The amount of NS stored in the substrate in each bench was relatively low as the water retained by coconut coir substrate varies from $28 \%$ to $72 \%$ of the substrate volume according to Evans and Stamps (1996). Notably, if the minimum level of NS storage $(28 \%)$ was to occur in this subirrigation system, there would be $9.4 \mathrm{~L}$ of NS retained in each bench rather than the $0.71 \mathrm{~L}$ found in this study, corresponding only to $3 \%$ of the volume. Thus, the small amount of substrate found in the containers resulted in very little amount of NS stored, suggesting that this subirrigation system functioned in a way similar to a hydroponic system. This response was more evident in the containers with older and larger seedlings, with roots that filled nearly the full internal volume.

As shown in Table 1 , there was an average leaking volume of $3.58 \mathrm{~L}$ per bench per irrigation event, although there was no significant difference between the units $(P=0.893)$. The differences in bench performance can be highlighted by the fact that one of the benches showed a leaking volume of $9.40 \mathrm{~L}$, while another one 
leaked only $0.43 \mathrm{~L}$ in a single irrigation (data not shown). Most of the leakings were caused by corroded openings due to the contact between the aluminum and NS. This effect was intensified by NS puddles in uneven benches. Another output component of the system was the evapotranspiration volume from the eucalyptus seedlings, estimated to be $1.07 \mathrm{~L} \cdot \mathrm{h}^{-1}$ per bench according to Eq. [1].

The application time was statistically significant for the units $[P<$ 0.001 (Table 2)], implying different irrigation times for each bench. Nevertheless, because application was an operation performed with high frequency, improvements in the irrigawater, nutrient, and electrical power savings and reduction in environmental pollution, as differences would be multiplied by 63 benches in each of six units with six irrigations per day.

Drainage times were significantly different between units $[P=0.05$ tion process could induce significant

(Table 2)], probably because of variation in the drainage area, which was altered by corrosion and obstructions caused by organic material. This variation between units also changed the dwell time of the containers in contact with NS $[P=0.045$ (Table 2)].

The average height of NS applied in the container was $3.6 \mathrm{~cm}$, which corresponded to $\approx 30 \%$ of the pot height $[P=0.55$ (Table 2)]. This level should be adequate for wetting most of the substrate by capillary action, as was observed by Barreto et al. (2012) for pine bark and coconut coir growing media. However, because of the low quantity of substrate inside the containers, the NS absorption was accomplished predominantly by the roots flooded in each irrigation event, indicating that this system was similar to a hydroponic system. As a result, the amount of water supplied per plant could increase or decrease by changing the time between applications.

The variation in the applied volume (Table l) affected the height

Table 2. Nutrient solution (NS) application $\left(\mathrm{T}_{\mathrm{ab}}\right)$ and drainage $\left(\mathrm{T}_{\mathrm{db}}\right)$ time per bench, dwell time $\left(\mathrm{D}_{t}\right)$, and the height of $\mathrm{NS}$ applied in the container $(\mathrm{H})$ per irrigation event in clonal eucalyptus seedling production. Data are the means of four replications.

\begin{tabular}{llccc}
\hline \multirow{2}{*}{ Unit } & $\mathrm{T}_{\mathrm{ab}}$ & $\mathrm{T}_{\mathrm{db}}$ & $\mathbf{D}_{\mathbf{t}}$ & \\
\cline { 2 - 4 } & & $(\mathrm{min})$ & & $\mathbf{H}$ \\
\hline 1 & $11.0 \mathrm{~b}^{\mathrm{y}}$ & $51.0 \mathrm{a}$ & $29.0 \mathrm{a}$ & $3.72 \mathrm{Ns}^{\mathrm{y}}$ \\
2 & $12.8 \mathrm{a}$ & $46.5 \mathrm{ab}$ & $24.9 \mathrm{~b}$ & $3.77 \mathrm{Ns}$ \\
5 & $11.0 \mathrm{c}$ & $46.5 \mathrm{ab}$ & $27.0 \mathrm{ab}$ & $3.50 \mathrm{Ns}$ \\
6 & $11.0 \mathrm{c}$ & $43.5 \mathrm{~b}$ & $26.9 \mathrm{ab}$ & $3.42 \mathrm{Ns}$ \\
Mean & 11.47 & 46.87 & 26.94 & 3.61 \\
$P$ value & $<0.001$ & 0.05 & 0.045 & 0.55 \\
$\mathrm{CV}(\%)^{\mathrm{x}}$ & 7.22 & 7.31 & 6.55 & 10.98 \\
\hline
\end{tabular}

${ }^{2} 1 \mathrm{~cm}=0.3937$ inch.

'Means followed by different letters in the column differ statistically by Tukey's test $(P<0.05)$; NS $=$ Nonsignificant ${ }^{\mathrm{x}}$ Coefficient of variation.

Table 3. Nutrient solution (NS) return to reservoir, evapotranspiration $\left(\mathrm{V}_{\mathrm{ET}}\right)$, storage efficiency $\left(\mathrm{SE}_{\mathrm{b}}\right)$, leaking $\left(\mathrm{L}_{\mathrm{b}}\right)$, application efficiency $\left(\mathrm{AE}_{\mathrm{b}}\right)$, and irrigation efficiency $\left(\mathrm{IE}_{\mathrm{b}}\right)$ percentages relative to the volume of NS applied per bench per irrigation event in clonal eucalyptus seedling production. Data are the means of four replications.

\begin{tabular}{|c|c|c|c|c|c|c|}
\hline \multirow[b]{2}{*}{ Unit } & Return & $\mathrm{V}_{\mathrm{ET}}$ & $S E_{b}$ & $\mathbf{L}_{\mathbf{b}}$ & $\mathrm{AE}_{\mathrm{b}}$ & $\mathrm{IE}_{\mathrm{b}}^{\mathrm{z}}$ \\
\hline & \multicolumn{6}{|c|}{$(\%)$} \\
\hline 1 & $97.62 \mathrm{Ns}^{\mathrm{y}}$ & $0.44 \mathrm{~b}^{\mathrm{y}}$ & $0.25 \mathrm{NS}$ & $1.69 \mathrm{NS}$ & $0.70 \mathrm{NS}$ & $98.31 \mathrm{NS}$ \\
\hline 2 & $97.87 \mathrm{Ns}$ & $0.52 \mathrm{ab}$ & $0.34 \mathrm{NS}$ & $1.26 \mathrm{NS}$ & $0.86 \mathrm{NS}$ & $98.74 \mathrm{NS}$ \\
\hline 5 & $97.34 \mathrm{NS}$ & $0.48 \mathrm{ab}$ & $0.38 \mathrm{NS}$ & $1.79 \mathrm{NS}$ & $0.86 \mathrm{NS}$ & $98.20 \mathrm{NS}$ \\
\hline 6 & $97.31 \mathrm{NS}$ & $0.55 \mathrm{a}$ & $0.38 \mathrm{NS}$ & $1.75 \mathrm{NS}$ & $0.93 \mathrm{NS}$ & $98.24 \mathrm{NS}$ \\
\hline Mean & 97.54 & 0.50 & 0.34 & 1.62 & 0.84 & 98.38 \\
\hline$P$ value & 0.9 & 0.025 & 0.679 & 0.924 & 0.453 & 0.924 \\
\hline $\mathrm{CV}(\%)^{\mathrm{x}}$ & 1.23 & 8.92 & 50.53 & 76.75 & 24.71 & 1.27 \\
\hline
\end{tabular}

${ }^{\mathrm{z}}$ It was assumed that all return NS was used.

${ }^{y}$ Means followed by different letters in the column differ statistically by Tukey's test $(P<0.05)$; NS $=$ Nonsignificant. ${ }^{\mathrm{x}}$ Coefficient of variation. of NS applied in the container and the dwell time within the benches (Table 2). According to Elliott et al. (2012), substrate moisture can change with different heights of NS and dwell times, and Barreto et al. (2012) found that substrate moisture increased with increased solution dwell time.

BeNCH EFFICIENCIES. Both the percentage of storage efficiency (NS stored in the substrate) and evapotranspirated volume by the crop did not exceed $0.84 \%$ of the total NS available and were lower than the bench leaking (1.62\%), showing that the NS loss volumes were larger than the volume consumed by the plants (Table 3 ). Therefore, the average bench application efficiency was only $0.84 \%$ because of the low amount of NS stored in by the substrate and consumed by the plants relative to the total volume of NS applied (Table 3 ).

The bench irrigation efficiency averaged $98.38 \%$ (Table 3 ), which is consistent with the recommendations proposed by Dumroese et al. (2006), indicating that recirculating subirrigation systems are very efficient. In contrast, Salvador (2010) found that the irrigation efficiency of a sprinkler system in 'Limeira' Rangpur lime (Citrus limonia) rootstock seedlings production in a similar container and greenhouse was only $33.6 \%$. These results confirm the potential of subirrigation for improving irrigation efficiency, assuming the use of welldesigned equipment with no leakages and recirculation systems with NS reuse.

In Table 3, the percentage of NS that was returned to the reservoirs was, on average, $97.54 \%$ of the applied volume. The total volume of NS used in subirrigation management will define the reservoir storage needs and will affect the pumping energy costs as well.

UNIT AND SYSTEM EFFICIENCIES. To estimate the efficiency parameters, we used the total volume of $36,500 \mathrm{~L}$ of NS in each irrigation unit, resultant from the sum of the initial volume of $19,000 \mathrm{~L}$ in the reservoirs and a replenishment volume of $2500 \mathrm{~L}$ every $2 \mathrm{~d}$. This NS volume supplied the 63 subirrigation benches, which were irrigated six times per day over the course of $15 \mathrm{~d}$.

The breakdown of NS used per unit (i.e., substrate storage, crop evapotranspiration, bench leakings, 


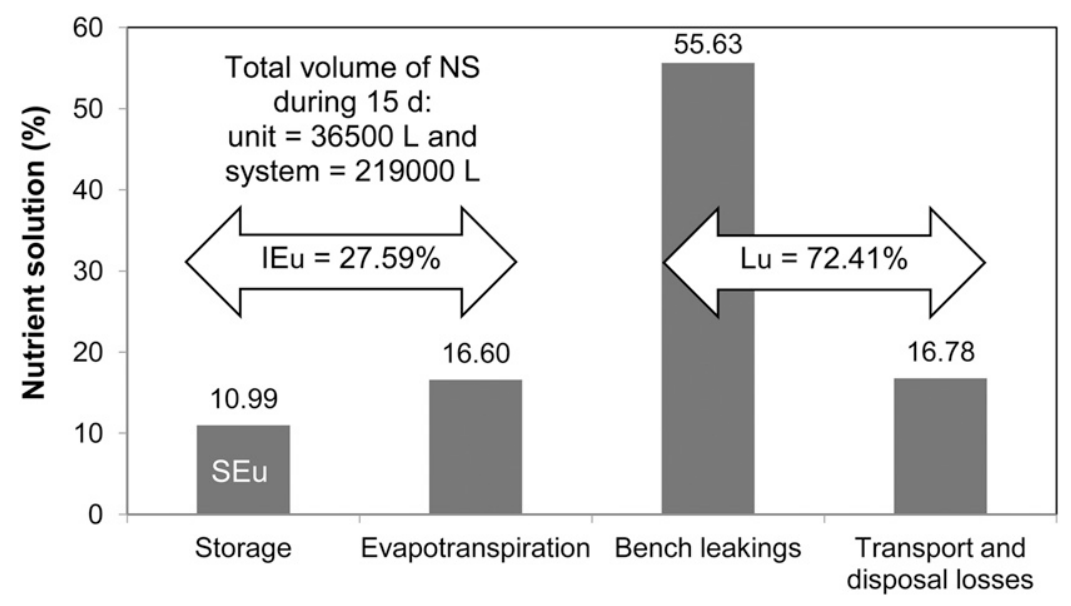

Fig. 3. Breakdown of nutrient solution (NS) used in each irrigation unit into the components of substrate storage $\left(\mathrm{SE}_{\mathrm{u}}\right)$, crop evapotranspiration, bench leakings, and system transport (supply and drainage) and disposal losses in an irrigation cycle for clonal eucalyptus seedling production. The sum of $S_{\mathrm{u}}$ and crop evapotranspiration represents the unit irrigation efficiency $\left(\operatorname{IE}_{u}\right)$. The sum of the bench leakings and transport and disposal losses indicates the water lost by the unit $\left(\mathrm{L}_{\mathrm{u}}\right) ; 1 \mathrm{~L}=0.2642$ gal.

and system transport and disposal) in an irrigation cycle of $15 \mathrm{~d}$ can be observed in Fig. 3. We also inserted the average efficiency parameters in this figure. The NS stored in the containers, or the storage efficiency, was $10.99 \%(4011 \mathrm{~L})$ on average of the total NS available in a 15-d irrigation period. Adding this value to the evapotranspirated average volume of $16.6 \%(6059 \mathrm{~L})$ results in a total of $27.59 \%(10,070 \mathrm{~L})$ and represents the irrigation efficiency per unit (Fig. 3). Average volume required to counter bench leaking reached $55.63 \%(20,305$ L) (Fig. 3). The remaining NS amount of $16.78 \%$ $(6125 \mathrm{~L})$ represents the quantity of NS lost during water supply and drainage and the NS disposal at the end of the irrigation cycle (Fig. 3).

The sum of the losses by the water supply, drainage, leakings, and disposal in the water treatment plant after $15 \mathrm{~d}\left(\mathrm{~L}_{\mathrm{u}}\right)$ represented $72.41 \%$ of the available NS per unit $(26,430 \mathrm{~L})$ (Fig. 3). The high NS losses resulted in a low volume effectively consumed by plants (only $27.59 \%$ ). All the losses imply in the direct disposal of NS into the ground (just part goes to the water treatment plant as well), with the potential for contamination of the groundwater by fertilizers and pesticides, if not treated appropriately (Mangiafico et al., 2010). According to Pinto et al. (2008), the disposal of NS should be minimized to reduce these environmental impacts and to increase water use efficiency and plant quality.

Assuming an NS system capacity of $219,000 \mathrm{~L}(36,500 \mathrm{~L}$ for each of six irrigation units) in each $15 \mathrm{~d}$ of irrigation, the irrigation efficiency represented $27.59 \%$ of this total volume and corresponded to a quantity of 60,422 L of NS consumed by the plant. All other uses totaled $72.41 \%$, corresponding to a volume of $158,578 \mathrm{~L}$. In the case of the system evaluated in this study, NS leaking totaled $55.63 \%(121,830 \mathrm{~L})$, and part of this volume was discarded directly into the ground beneath the greenhouse (Fig. 3). The effects of the low irrigation efficiency of the system resulted in both financially and environmentally undesirable impacts. These results were the consequence of various causes, including limited knowledge of the system, limited information about the subirrigation equipment and its operation, and even by the time the equipment had been in use.

The results from this study demonstrated that the substrate was expelled from the growth container because of the vigorous growth of plant roots, which reduced both the amount of NS stored and taken up by the plants. This process required constant irrigation, making the system equivalent to a hydroponic system, with water and nutrients being supplied to the plants with a high frequency, which kept the containers partially immersed in the NS and did not use the full substrate container capacity. To reduce this problem, the container size should be increased to keep the root system inside the pot, the frequency of subirrigation should be reduced, the leakings need to be fixed, and an automated system to control irrigation based on soil moisture sensors could be used rather than using a rigid scale (Ferrarezi et al., 2013). These authors, who used subirrigation equipment developed for the production of 'Limeira' Rangpur lime rootstock seedlings in tropical conditions, achieved zero runoff and plant cycle anticipation, allowing more cultivation cycles over time because of the increase of NS use efficiency.

\section{Conclusions}

Our results confirmed that this specific subirrigation system in clonal eucalyptus seedling production has some limitations, such as low irrigation and application efficiency, both caused by the high irrigation frequency, leaking of benches and pipes, and the excess volume of NS disposal.

The subirrigation benches presented an adequate irrigation efficiency, but a low application efficiency caused by the constant return of NS because of the high irrigation frequency and the excess of losses from leaking and disposal of NS after $15 \mathrm{~d}$ of cultivation. The subirrigation operated like a hydroponic system, reducing the overall system irrigation efficiency and the substrate storage efficiency, requiring improvements regarding equipment design, operation, water and nutrients use efficiency, and management.

This performance assessment procedure should be used in other subirrigation facilities to test their efficacy, but the absence of commercial equipment in our region makes this comparison unavailable at this time. Future studies should apply these features to other subirrigation systems for different crops, and the proposed methodology can be easily used to assess the efficiency parameters.

\section{Literature cited}

Allen, R.G., L.S. Pereira, D. Raes, and M. Smuth. 1998. Crop evapotranspiration: Guidelines for computing crop water requirements. FAO Bul. 56. 
Andriolo, J.L., M.P. Boemo, and J.V. Bonini. 2001. Growth and development of tomato and melon seedlings using irrigation methods of overhead, ebb-andflow and floating. Horticultura Brasileira 19:200-203.

Barreto, C.V.G., R. Testezlaf, and C.A. Salvador. 2012. Capillary water rise in coconut and pine bark substrates. Bragantia 71:385-393.

Dumroese, R.K., J.R. Pinto, D.F. Jacobs, A.S. Davis, and B. Horiuchi. 2006. Subirrigation reduces water use, nitrogen loss, and moss growth in a container nursery. Native Plants J. 7:253-261.

Elliott, G., R. McAvoy, and M. Gent. 2012. Subirrigation: Watering from the ground up. 16 Sept. 2013. <http:// www.greenhousegrower.com/article/ 26828 /subirrigation-watering-fromthe-ground-up $>$.

Evans, M.R. and R.H. Stamps. 1996. Growth of bedding in sphagnum peat and coir dust-based substrates. J. Environ. Hort. 14:187-190.

Fernández, M.D., S. Bonachela, F. Orgaz, R. Thompson, J.C. López, M.R. Granados, M. Gallardo, and E. Fereres. 2010. Measurement and estimation of plastic greenhouse reference evapotranspiration in a Mediterranean climate. Irr. Sci. 28:497509 .

Ferrarezi, R.S. and M.W. van Iersel. 2011. Monitoring and controlling subirrigation with soil moisture sensors: A case study with hibiscus. Proc. Southern Nursery Assn. Res. Conf. 56:187-191.

Ferrarezi, R.S., M.D. Ribeiro, M.W. van Iersel, and R. Testezlaf. 2013. Subirrigation controlled by capacitance sensors for citrus rootstock production. HortScience 48:S142 (abstr.)

Heermann, D.F. and K.H. Solomon. 2007. Efficiency and uniformity, p. 108119. In. G.J. Hoffman, R.G. Evans, M.E. Jensen, D.L. Martin, and R.L. Elliott. Design and operation of farm irrigation systems. Amer. Soc. Agr. Biol. Eng., St Joseph, MI.

Keller, J. and D. Karmeli. 1975. Trickle irrigation design. Rain Bird Sprinkler Manufacturing Corp., Glendora, CA.

Mangiafico, S.S., J. Newman, M. Mochizuki, D. Zurawski, D.J. Merhaut, and B. Faber. 2010. Nurseries surveyed in southern California adopt best practices for water quality. Calif. Agr. 64:26-30.

Montero, J.I., N. Castilla, E.G. Ravé, and F. Bretones. 1985. Climate under plastic in the Almeria area. Acta Hort. 170:227-234.

Montesano, F., A. Parente, and P. Santamaria. 2010. Closed cycle subirrigation with low concentration nutrient solution can be used for soilless tomato production in saline conditions. Sci. Hort. 124:338-344.

Peel, M.C., B.L. Finlayson, and T.A. McMahon. 2007. Updated world map of the Köppen-Geiger climate classifica- tion. Hydrol. Earth Syst. Sci. 11:16331644.

Pinto, J.R., R.A. Chandler, and R.K. Dumroese. 2008. Growth, nitrogen use efficiency, and leachate comparison of subirrigated and overhead irrigated pale purple coneflower seedlings. HortScience 43:897-901.

Rosenberg, N.J., M.S. McKenny, and P. Martin. 1989. Evapotranspiration in greenhouse-warmed world: A review and a simulation. Agr. For. Meteorol. 47:303-320.

Salvador, C.A. 2010. Sistema de irrigação por capilaridade na produção de portaenxertos de mudas cítricas na fase de sementeira. University of Campinas, Campinas, Brazil, MS Thesis.

Schmal, J.L., R.K. Dumroese, A.S. Davis, J.R. Pinto, and D.F. Jacobs. 2011. Subirrigation for production of native plants in nurseries: Concepts, current knowledge, and implementation. Native Plants J. 12:81-93.

van Der Post, C.J., J.J. van Shie, and R. Graaf. 1974. Basic problems of water relationship: Energy balance and water supply in glasshouses the West-Nertherlands. Acta Hort. 35:13-21.

van Iersel, M.W., R.D. Oetting, D.B. Hall, and J.G. Kang. 2001. Application technique and irrigation method affect imidacloprid control of silverleaf whiteflies (Homoptera: Aleyrodidae) on poinsettias. J. Econ. Entomol. 94:666672. 